\title{
Karakteristik dan Aktivitas Antibakteri Scaffold Membran Cangkang Telur yang Diaktivasi Karbonat Apatit
}

\author{
Mirantini Aprilisna*, Bambang Sunendar**, Haris Budi Widodo*, dan Catur Aditya* \\ ${ }^{*}$ Kedokteran Gigi Universitas Jenderal Soedirman, Purwokerto, Jawa Tengah, Indonesia \\ ${ }^{* *}$ Fakultas Teknik Industri, Institut Teknologi Bandung, Jawa Barat, Indonesia \\ J. Dr. Soeparno, Kampus Karangwangkal Gedung E, Purwokerto, Jawa Tengah, Indonesia; e-mail: aprilisna92@gmail.com
}

\begin{abstract}
ABSTRAK
Struktur tulang yang hilang akibat penyakit periodontal dan trauma dapat ditanggulangi dengan pemasangan graft. Pemasangan graft rentan akan adanya invasi bakteri sehingga alternatifnya dibuat scaffold dengan aktivitas antibakteri. Teknik jaringan berupa pembuatan scaffold harus memiliki sifat biokompatibel, biodegradasi, dan bioaktif. Penelitian ini menggunakan membran cangkang telur, larutan alginat dan kitosan, karbonat apatit dan larutan SBF Kokubo. Penelitian ini bertujuan mengetahui karakteristik dan aktivitas antibakteri scaffold membran cangkang telur yang diaktivasi karbonat apatit. Penelitian ini menggunakan metode eksperimental laboratoris dengan jumlah kelompok sampel sebanyak lima kelompok, yaitu sampel A membran cangkang telur, sampel B membran cangkang telur + karbonat apatit, sampel C membran cangkang telur + karbonat apatit + SBF selama 7 hari, sampel D membran cangkang telur + karbonat apatit + SBF selama 14 hari, dan sampel E membran cangkang telur + karbonat apatit + SBF selama 21 hari. Uji sampel yaitu karakterisasi menggunakan ATR FTIR dan SEM, serta uji aktivitas antibakteri menggunakan metode difusi. Hasil

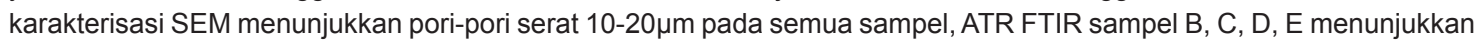
peningkatan gugus apatit dibanding sampel A. Pengujian antibakteri terhadap Staphylococcus aureus menunjukkan zona bening pada setiap sampel. Perhitungan jumlah koloni setiap sampel yaitu terbanyak koloninya sampel $A \pm 78 \times 10^{5}$ $\mathrm{CFU} / \mathrm{ml}$, dan paling sedikit koloninya sampel $\mathrm{B} \pm 14 \times 10^{5} \mathrm{CFU} / \mathrm{ml}$. Kesimpulan penelitian ini yaitu karakteristik dan aktivitas antibakteri scaffold membran cangkang telur yang diaktivasi karbonat apatit mengandung bahan bioaktif, bersifat biodegradasi dan menunjukkan aktivitas antibakteri.
\end{abstract}

Maj Ked Gi Ind. Juni 2015; 1(1): hal 59-67

Kata Kunci: Membran cangkang telur, karbonat apatit, karakterisasi, antibakteri, scaffold

\begin{abstract}
Characteristic And Antibacterial Activity Of Egg-Shell Membrane Scaffold Activated By Carbonate Apatite. The loss of bone structure that can be caused by periodontal disease and trauma can be treated by installation of graft. The installation of graft is vulnerable to bacterial invasion, so that the alternative is to make a scaffold with antibacterial activity. Scaffold manufacturing in engineering system must have biocompatible, biodegradable, and bioactive properties. This research used egg-shell membrane (ESM) as scaffold template, alginate, chitosan, carbonate apatite, and SBF solution. The purpose of this research is to know the characteristics, and antibacterial activity of eggshell membrane scaffold which is activated by carbonate apatite. This research used laboratory experimental method by dividing the samples into five groups that were ESM as sample A, ESM with carbonate apatite as sample B, ESM with carbonate apatite soaked in SBF sol for 7days as sample C, ESM with carbonate apatite soaked in SBF sol for 14 days as sample $D$, and ESM with carbonate apatite soaked in SBF sol for 21days as sample $E$. Then the testing on each sample was conducted: the test for characteristics used ATR FTIR and SEM, while the antibacterial activity test used diffusion method. The results of SEM charaterization from all samples show that the size of pores is 10-20um. ATR FTIR results of sample $B, C, D$ and $E$ show an increase in functional groups of apatite compared to sample A. Antibacterial testing on Staphylococcus aureus shows inhibition zone. Based on the calculation of colony number the highest number is sample $A( \pm 78 \times 105 \mathrm{CFU} / \mathrm{ml})$, and the least is sample $E \pm 14 \times 105 \mathrm{CFU} / \mathrm{ml}$. The conclusion of this research is that the characteristic and antibacterial activity test of egg-shell membrane scaffold activated by carbonate apatite have bioactive and biodegradable material, and show antibacterial activities.
\end{abstract}

Maj Ked Gi Ind. Juni 2015; 1(1): hal 59-67

Keywords: Egg-shell membrane, carbonate apatite, characterization, antibacterial, scaffold

\section{PENDAHULUAN}

Tulang alveolar merupakan bagian tulang yang memiliki peranan sebagai penyokong gigi. Kerusakan jaringan tulang pembentuk dan penyokong gigi dapat menyebabkan hilangnya kepadatan struktur tulang. ${ }^{1}$ Struktur tulang yang hilang akibat trauma dan tidak ditanggulangi memungkinkan terjadi invasi bakteri. Bakteri pada tulang rahang yang sering ditemukan setelah mengalami trauma atau operasi yaitu Fusobacterium nucleatum, 
Parvimonas micra, dan Staphylococcus aureus. ${ }^{2}$ Metode alternatif yang dapat digunakan adalah pembuatan scaffold dengan aktivitas antibakteri. Pembuatan scaffold harus memenuhi prinsip rekayasa jaringan yaitu dibuat dari bahan material yang memiliki sifat biokompatibel, biodegradasi, dan bioaktif. $^{3}$

Bahan dasar scaffold yang memenuhi kriteria bahan material yang baik yaitu eggshell membrane atau membran cangkang telur. Membran cangkang telur merupakan bahan alam yang memiliki sifat biokompatibel dan biodegradasi, serta struktur berpori sehingga membran kulit telur dapat diaplikasikan sebagai template dalam sintesis scaffold. ${ }^{4}$ Scaffold dengan basis membran cangkang telur ini dapat diberi bahan polimer seperti sodium alginat dan kitosan.

Polimer membran cangkang telur, alginat dan kitosan yang sudah terbentuk memerlukan material bioaktif. Pembuatan membran hidroksiapatit dapat terbentuk di atas permukaan membran cangkang telur melalui metode self assembly dengan cara merendam membran cangkang telur dalam sumber apatit. Membran hidroksiapatit terbentuk karena adanya ikatan kimia (chemisorpsi) yang kuat antara functional group dari membran cangkang telur dan sumber apatit. ${ }^{5}$

Material bioaktif yang digunakan dalam penelitian ini yaitu karbonat apatit. Karbonat apatit merupakan material bioaktif hasil substitusi ion karbonat dengan gugus fosfat dari hidroksiapatit. ${ }^{6}$ Hidroksiapatit memiliki ion hidroksida $\left(\mathrm{OH}^{-}\right)$yang merupakan radikal bebas dan kaya oksidan. Sifatnya reaktif dan bereaksi dengan beberapa biomolekul serta berefek letal pada bakteri. ${ }^{7}$

Scaffold yang disintesis diuji secara in vitro dalam larutan Simulated Body Fluid (SBF) Kokubo. Larutan SBF Kokubo memiliki kandungan ion yang hampir mendekati ion plasma darah manusia, yaitu $\mathrm{Na}^{+}, \mathrm{K}^{+}, \mathrm{Mg}^{2+}, \mathrm{Ca}^{2+}, \mathrm{Cl}^{-}, \mathrm{HCO}_{3}^{-}, \mathrm{HPO}_{4}{ }_{4}^{2-}$, dan $\mathrm{SO}_{4}{ }^{2-}$ karena kemiripannya larutan ini dapat digunakan sebagai larutan simulasi sebelum scaffold dimasukkan ke dalam tubuh manusia. ${ }^{8}$ Perubahan fisik yang diamati adalah luruhnya material karena adanya interaksi dengan lingkungan. Menurut hasil pengamatan, proses peleburan material dilihat sedikit demi sedikit melalui permukaan material. ${ }^{9}$

Berdasarkan latar belakang tersebut peneliti tertarik untuk mengetahui karakteristik dan aktivitas antibakteri scaffold membran cangkang telur yang diaktivasi karbonat apatit sehingga didapatkan scaffold dengan karakteristik bioaktif, biodegradasi dan memiliki aktivitas antibakteri.

\section{METODE PENELITIAN}

Penelitian ini dilakukan di Advanced Material Processing Laboratory, FMIPA-ITB, dan Sekolah Farmasi ITB. Penelitian ini merupakan penelitian eksperimental laboratoris dengan sumber data diambil langsung selama proses penelitian di laboratorium. Sampel pada penelitian ini dibagi menjadi lima kelompok, yaitu kelompok $\mathrm{A}$ (scaffold membran cangkang telur sebagai kontrol), kelompok B (scaffold membran cangkang telur yang diaktivasi karbonat apatit), kelompok C (scaffold membran cangkang telur yang diaktivasi karbonat apatit yang direndam dalam larutan SBF selama 7 hari), kelompok D (scaffold membran cangkang telur yang diaktivasi karbonat apatit yang direndam dalam larutan SBF selama 14 hari), dan kelompok $\mathrm{E}$ (scaffold membran cangkang telur yang diaktivasi karbonat apatit yang direndam dalam larutan SBF selama 21 hari). Jumlah sampel pada masing-masing kelompok adalah 4 buah. Setiap sampel diuji dan hasil dideskripsikan untuk mengetahui bagaimana karakteristik dan aktivitas antibakteri dari membran cangkang telur yang diaktivasi karbonat apatit untuk aplikasi material scaffold hasil sintesis.

Alat yang digunakan dalam penelitian ini adalah gelas kimia 250 dan $500 \mathrm{ml}$, gelas ukur 25 dan $50 \mathrm{ml}$, pipet tetes, cawan petri, pinset plastik, spatula, magnetic stirrer, timbangan digital, pot zalp, dan indikator $\mathrm{pH}$.

Bahan yang digunakan dalam penelitian ini adalah membran cangkang telur, sodium hidroksida, asam nitrat $25 \%$, sodium alginat, chitosan highly viscosity, calsium nitrat tetrahydrate, amonium hydrogen phosfat, calsium carbonate precipitate, larutan SBF Kokubo, aqua dm, dan aqua bidest. 
Cara pembuatan scaffold diawali dengan preparasi membran cangkang telur. Preparasi membran cangkang telur diawali dengan pelepasan membran cangkang telur bagian dalam dengan cara manual. Setelah itu pelepasan lapisan membran cangkang telur bagian luar menggunakan larutan $\mathrm{HNO}_{3} 1 \mathrm{M}$, dan terakhir perendaman membran cangkang telur bagian luar atau outer membrane dalam $\mathrm{NaOH}$ 0,1 M selama 24 jam.

Langkah berikutnya pembuatan larutan alginat-kitosan, karbonat apatit dan larutan SBF Kokubo. Pertama pembuatan larutan alginat dan kitosan, yaitu larutan alginat $0,1 \%$ dan larutan kitosan $0,15 \%$, kemudian membran direndam ke dalam larutan alginat dan kitosan secara bergantian selama 1 jam. Kedua pembuatan larutan karbonat apatit. Pembuatan larutan karbonat apatit menggunakan prekursor berupa larutan calsium nitrat tetrahydrate, amonium hydrogen phosfat dan sodium hydrogen carbonate yang dilarutkan ke dalam aqua $\mathrm{dm}$. Membran cangkang telur yang sudah direndam dalam larutan alginat-kitosan langsung dimasukan ke dalam larutan karbonat apatit selama $24 \mathrm{jam}$. Ketiga pembuatan larutan SBF Kokubo. Pembuatan larutan SBF Kokubo dibuat $1,5 x$ SBF yang membutuhkan $\mathrm{NaCl}, \mathrm{NaHCO} 3, \mathrm{KCl}$, $\mathrm{K} 2 \mathrm{HPO} 4.3 \mathrm{H} 2 \mathrm{O}, \mathrm{MgCl} 2.6 \mathrm{H} 2 \mathrm{O}, \mathrm{CaCl} 2, \mathrm{Na} 2 \mathrm{SO} 4 \mathrm{ke}$ dalam $1000 \mathrm{ml}$ aquabides secara berurutan dan diberi buffer tris-hydroxymethyl animomethane
[(CH2OH)3CNH2] dan $\mathrm{HCl}$. Kemudian membran direndam selama 7, 14 dan 21 hari dengan mengganti larutan SBF setiap 3 hari sekali.

Langkah terakhir berupa pengujian sampel yaitu uji karakterisasi Scanning Electron Microscope (SEM), karakterisasi Attenuated Total ReflectanceFourier Transform Infrared (ATR FTIR), dan uji aktivitas bakteri. Pertama, karakterisasi SEM digunakan untuk melihat topografi permukaan dari suatu material. Sampel A, B, C, D, dan E dilakukan uji SEM untuk mengetahui struktur pori dan senyawa yang terdapat pada membran scaffold. Kedua, karakterisasi ATR FTIR bertujuan mengidentifikasi dan menentukan struktur material organik dan anorganik. Sampel A, B, C, D, dan E dilakukan uji ATR FTIR untuk mengetahui gugus fungsi senyawa yang terdapat pada membran scaffold. Ketiga metode yang digunakan untuk uji aktivitas bakteri yaitu diawali dengan metode difusi agar bertujuan mengukur zona bening/zona hambat, dan kedua perhitungan koloni untuk melihat jumlah koloni yang tumbuh. Sampel A, B, C, D, dan E diukur beratnya masing-masing $\pm 10 \mathrm{mg}$. Bakteri yang digunakan yaitu Staphylococcus aureus.

\section{HASIL PENELITIAN}

\section{A. Hasil Karakterisasi SEM}

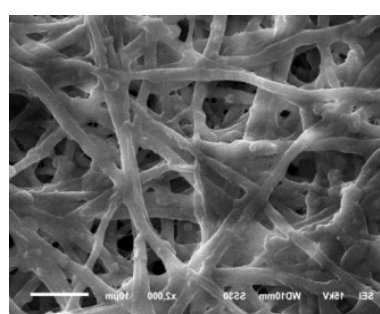

(A)

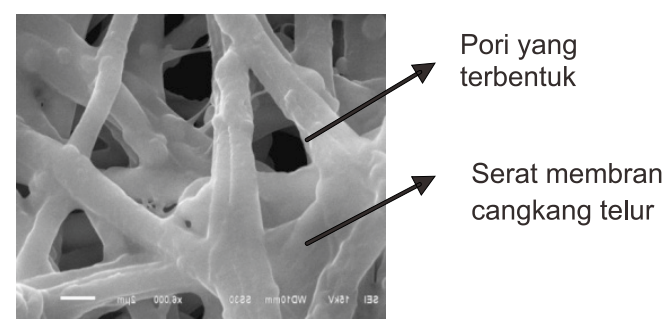

(B)

Gambar 1. Hasil karakterisasi SEM Sampel A membran cangkang telur (A) perbesaran 2000x dan (B) perbesaran 6000x. Hasil menunjukkan pori-pori membran berukuran $10-20 \mu \mathrm{m}$ dan serat membran $2 \mu \mathrm{m}$. 
2. Sampel B

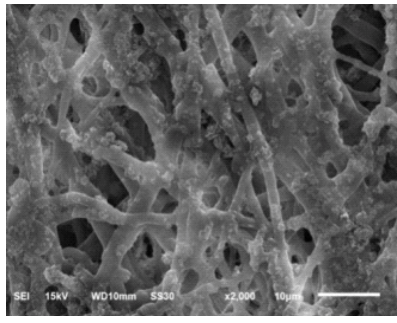

(A)

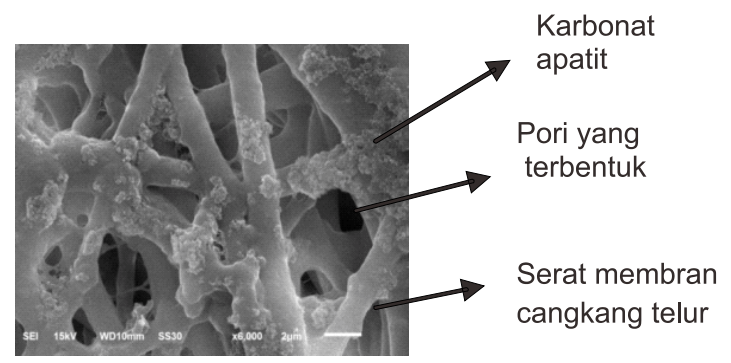

(B)

Gambar 2. Hasil karakterisasi SEM Sampel B membran cangkang telur + karbonat apatit (A) perbesaran 2000x dan (B) perbesaran 6000x. Hasil menunjukkan perlekatan karbonat apatit pada serat membran.

\section{Sampel C}

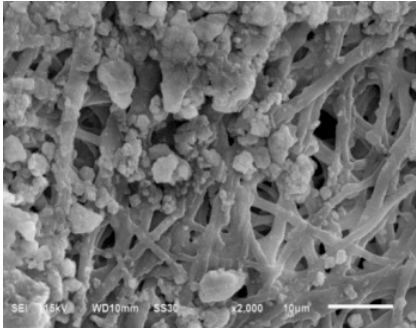

(A)

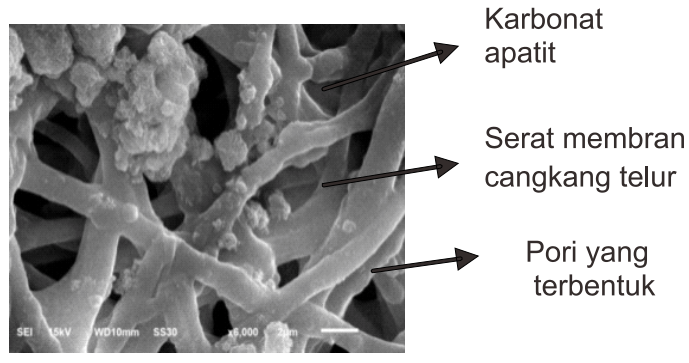

(B)

Gambar 3. Hasil karakterisasi SEM Sampel $C$ membran cangkang telur + karbonat apatit + SBF 7 hari (A) perbesaran 2000x dan (B) perbesaran 6000x. Hasil menunjukkan perlekatan apatit pada serat lebih banyak dari Sampel B.

4. Sampel D

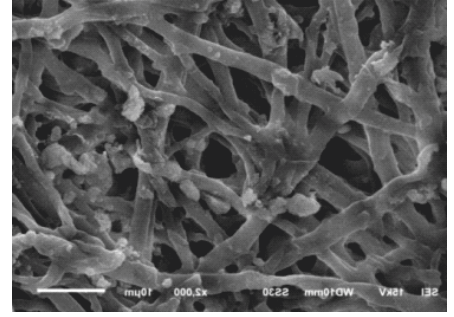

(A)

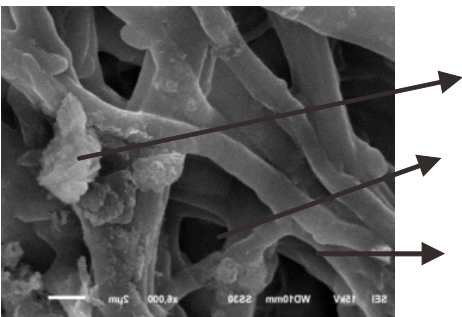

(B)

Karbonat

apatit

Pori yang

terbentuk

Serat membran cangkang telur

Gambar 4. Hasil karakterisasi SEM Sampel D membran cangkang telur + karbonat apatit + SBF 14 hari (A) perbesaran 2000x dan (B) perbesaran 6000x. Hasil menunjukkan pelepasan apatit pada permukaan serat membran.

5. Sampel E

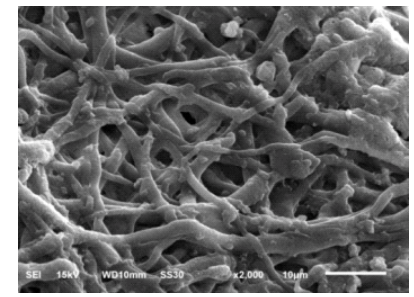

(A)

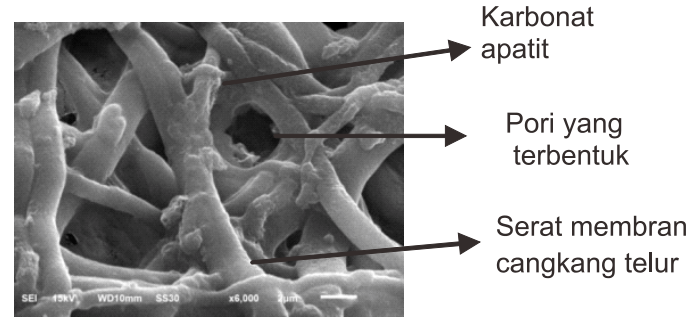

(B)

Gambar 5. Hasil karakterisasi SEM Sampel E membran cangkang telur + karbonat apatit + SBF 21 hari (A) perbesaran 2000x dan (B) perbesaran 6000x. Hasil menunjukkan pelepasan apatit lebih banyak dari Sampel D. 


\section{B. Hasil Karakterisasi ATR FTIR}

1. Sampel A

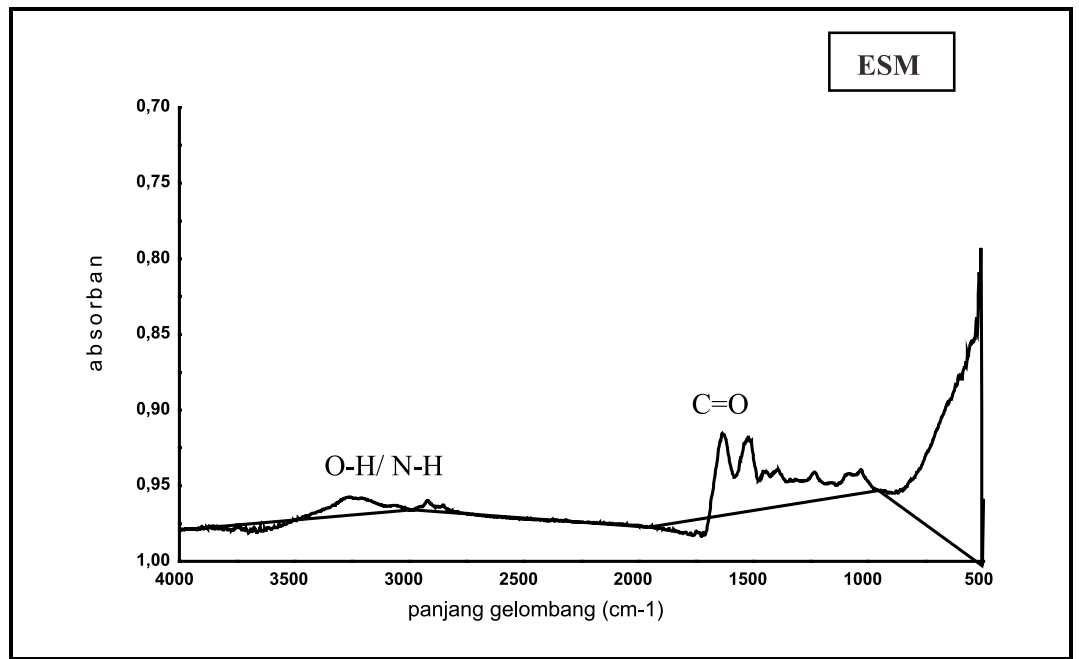

Gambar 6. Grafik ATR FTIR Sampel A membran cangkang telur

2. Sampel B, C, D, E

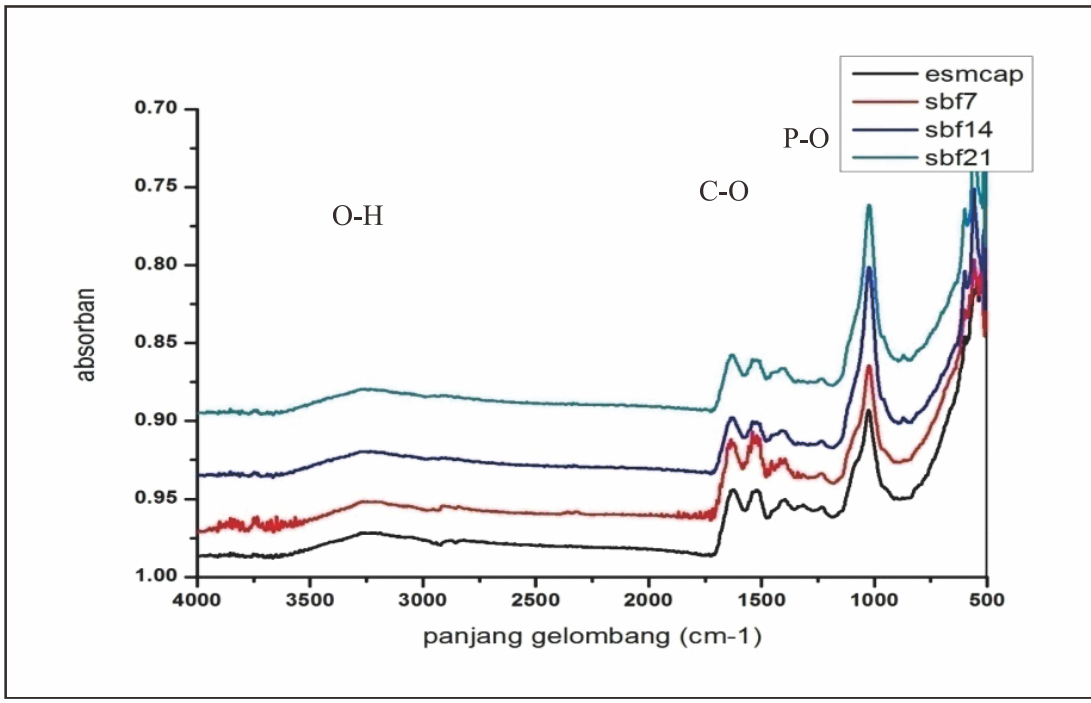

Gambar 7. Perbandingan grafik ATR FTIR sampel B, C, D dan E

\section{Hasil Uji Aktivitas Antibakteri}

1. Tahap 1 Metode Difusi

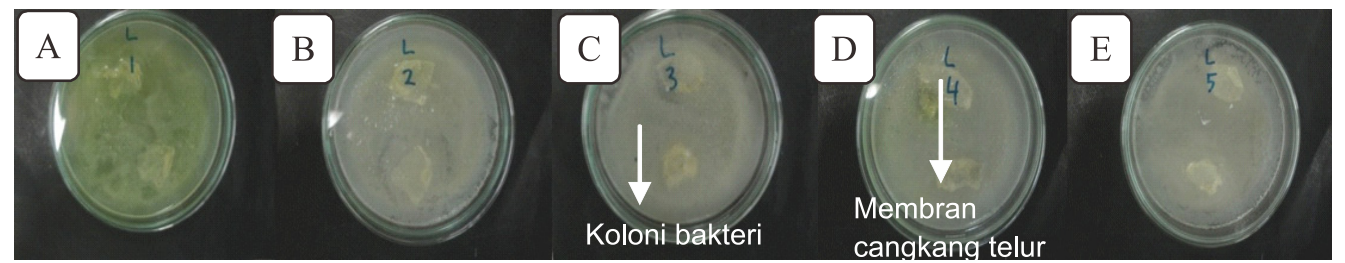

Gambar 8. Scaffold sebelum dilepas terhadap bakteri S.aureus

A) sampel A, B) sampel B, C) sampel C, D) sampel D, E) sampel E 


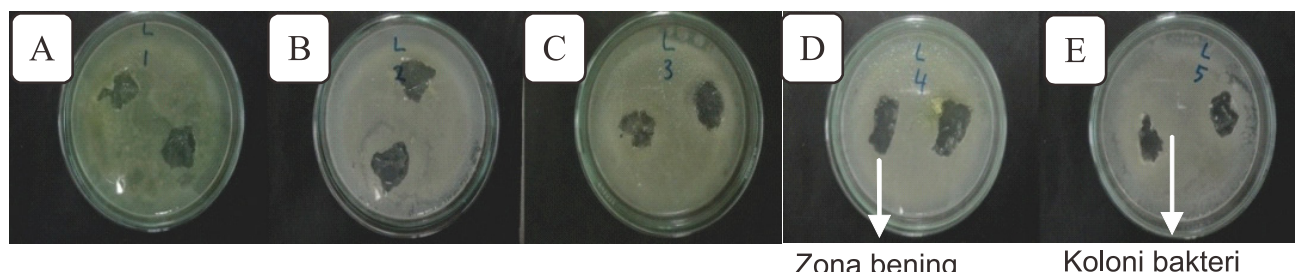

Zona bening

Koloni bakteri

Gambar 9. Scaffold setelah dilepas terhadap bakteri S.aureus A) sampel A, B) sampel B,

C) sampel C, D) sampel D, E) sampel E

2. Tahap 2 Perhitungan Koloni
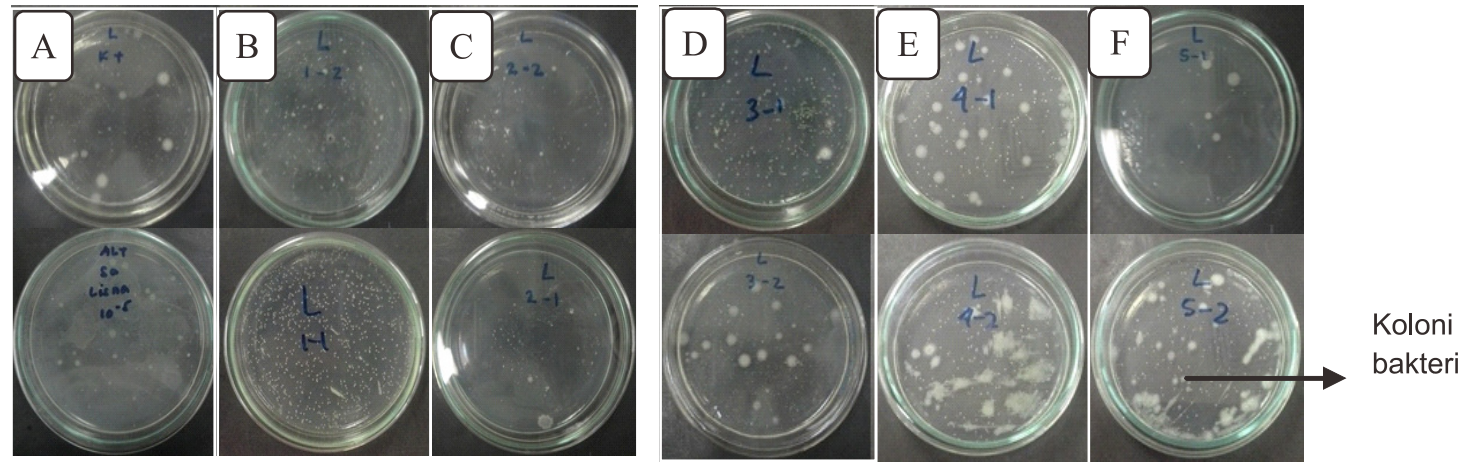

Gambar 10. Hasil uji aktivitas antibakteri tahap 2 terhadap bakteri S.aureus

A) kontrol, B) sampel A, C) sampel B, D) sampel C, E) sampel D, F) sampel $E$

3. Jumlah koloni bakteri S. aureus

Tabel 1. Jumlah koloni (CFU/ml) bakteri S. Aureus

\begin{tabular}{|l|l|l|l|l|l|l|}
\hline No & Kontrol & Sampel A & Sampel B & Sampel C & Sampel D & Sampel E \\
\hline 1 & \multirow{2}{*}{$138 \times 10^{5}$} & $73 \times 10^{5}$ & $46 \times 10^{5}$ & $29 \times 10^{5}$ & $19 \times 10^{5}$ & $13 \times 10^{5}$ \\
2 & & $83 \times 10^{5}$ & $58 \times 10^{5}$ & $39 \times 10^{5}$ & $18 \times 10^{5}$ & $16 \times 10^{5}$ \\
\hline
\end{tabular}

\section{PEMBAHASAN}

\section{A. Analisa Karakterisasi SEM dan ATR FTIR}

Hasil SEM menunjukkan ukuran serat membran pada sampel $A, B, C, D$ dan $E$ berkisar antara $2 \mu \mathrm{m}$ dilihat dengan perbesaran $6000 \mathrm{x}$ dan pori-pori serat membran berkisar 10-20 $\mu \mathrm{m}$ dengan perbesaran 2000x. Pori-pori yang terbentuk cukup untuk pertumbuhan osteoblas yaitu 20-30 $\mu \mathrm{m}$. Penggunaan larutan $\mathrm{NaOH}$ 0,1 M selama 24 jam dapat mengaktifkan permukaan membran sehingga pembentukan apatit lebih banyak diatas permukaan dan pori-pori membran lebih terbuka. $\mathrm{NaOH}$ dapat menetralkan sisa-sisa asam pada membran dan berfungsi menghilangkan non-collagenous protein dalam membran cangkang telur. ${ }^{5}$
Membran cangkang telur terlebih dahulu direndam dalam larutan kitosan dan alginat. Kitosan sebagai pendispersi akan mempercepat pertumbuhan apatit pada permukaan membran. Kitosan juga memiliki banyak gugus amino yang memudahkan gugus $\mathrm{OH}^{-}$mudah berikatan. Gugus $\mathrm{OH}^{-}$banyak ditemukan pada alginat. Selain menambah fleksibelitas membran, perendaman membran pada alginat dapat meningkatkan gugus $\mathrm{OH}^{-}$pada permukaan membran. Semakin banyak gugus $\mathrm{OH}^{-}$maka ikatan senyawa aktif $\mathrm{Ca}^{2+}$ dan $\mathrm{PO}_{4}^{3-}$ semakin banyak. ${ }^{5}$

Senyawa aktif yang digunakan berupa karbonat apatit. Karbonat apatit mengadung gugus $\mathrm{Ca}^{2+}, \mathrm{PO}_{4}^{3-}, \mathrm{OH}^{-}$dan $\mathrm{CO}^{3-}$ yang berikatan secara kimia. Hasil ATR FTIR pada Gambar 7 
menunjukkan peningkatan gugus fungsi $\mathrm{P}-\mathrm{O}$ yaitu $\mathrm{PO}_{4}{ }^{3-}$, dan $\mathrm{C}-\mathrm{O}$ yaitu $\mathrm{CO}_{3}^{-}$setelah perendaman scaffold dalam larutan karbonat apatit. Hal ini membuktikan scaffold yang disintesis memiliki sifat bioaktif karena mengandung senyawa karbonat $\left(\mathrm{CO}_{3}{ }^{-}\right)$dan posfat $\left(\mathrm{PO}_{4}{ }^{3}\right)^{-}$. Penambahan karbonat apatit akan mempengaruhi interkonektivitas dari scaffold. Hal ini sesuai dengan hasil karakterisasi SEM pada sampel B berupa perlekatan apatit pada permukaan membran cangkang telur (Gambar 2). ${ }^{10}$

Perendaman selanjutnya yaitu menggunakan larutan SBF. Larutan SBF tidak hanya mengandung garam melainkan juga hidroksiapatit. Hidroksiapatit akan meningkat seiring pergantian larutan SBF setiap tiga kali sehari. Pembentukan hidroksiapatit semakin banyak dengan semakin lamanya waktu perendaman dalam larutan SBF Kokubo sebagai sumber hidroksiapatit. Hal ini terbukti dengan adanya penumpukan apatit pada sampel $C$ lebih banyak dibanding sampel B dilihat dari Gambar 3 dengan perbesaran 2000x. Sampel C berupa membran cangkang telur-karbonat apatit yang direndam dalam larutan SBF selama 7 hari. Hal ini sejalan dengan proses biomimetic tulang terjadi pada hari ke 7 sampai 14. Biomimetic apatit menunjukkan diferensiasi sel-sel stroma sumsum tulang sepanjang garis osteogenic. ${ }^{11}$

Penurunan apatit pada permukaan serat membran sampel D dilihat pada Gambar 4. Hal ini terjadi karena degradasi dari polimer alginat dan kitosan, sehingga apatit yang menempel pada serat lepas dari permukaan serat membran cangkang telur. Apatit yang lepas pada permukaan terperangkap dalam pori-pori membran terlihat pada perbesaran 6000x. Sama halnya pada sampel $E$ dilihat pada Gambar 5 yang menunjukkan penurunan jumlah apatit pada permukaan membran lebih banyak dibanding sampel D. Hal ini membuktikan bahwa polimer pada scaffold memiliki sifat degradasi.

Apatit mulai terbentuk pada membran yang direndam dalam larutan SBF Kokubo selama 6 hari. Semakin lama perendaman maka diameter serat akan semakin menebal. Perbedaan terjadi setelah membran direndam selama 12 hari. Perendaman menunjukkan penurunan serat membran. Hal ini disebabkan karena sifat biodegradasi dari serat membran yang mengandung senyawa kitosan. ${ }^{5}$

Kitosan dengan persentasi tinggi dapat mempercepat proses biodegradasi. Penelitian Ardhananeswari (2013), menunjukkan besaran pori-pori scaffold dengan metode frezee-drying yaitu $60 \%$ kitosan menghasilkan pori-pori sebesar $50 \mu \mathrm{m}, 70 \%$ kitosan menghasilkan $100 \mu \mathrm{m}$ dan $80 \%$ kitosan menghasilkan $200 \mu \mathrm{m}^{12}$

\section{B. Analisa Uji Aktivitas Antibakteri}

Berdasarkan hasil pengujian sampel $A$, B, C, D, dan E melalui tahap 1 berupa metode difusi agar pada Gambar 8 tidak ditemukan zona bening/zona hambat pada semua sampel terhadap Stapylococcus aureus. Zona bening terlihat setelah membran dilepas dilihat pada Gambar 9. Ada perbedaan zona bening pada setiap sampel, hal ini menjelaskan bahwa setiap sampel memiliki aktivitas antibakteri yang berbeda. Selanjutnya diteruskan pada tahap 2 berupa metode perhitungan koloni untuk memastikan besaran aktivitas antibakteri pada setiap sampel dilihat dari jumlah koloni yang tumbuh.

Hasil pengujian sampel tahap 2 (Gambar 10) dapat dilihat pada Tabel 1 dengan hasil adanya penurunan jumlah koloni Staphylococcus aureus dari sampel A, B, C, D, dan E. Jumlah koloni pada kontrol sebanyak $138 \times 10^{5} \mathrm{CFU} / \mathrm{ml}$. Penurunan koloni mulai terlihat pada sampel $A$ dengan jumlah koloni menjadi $\pm 78 \times 10^{5} \mathrm{CFU} / \mathrm{ml}$. Sampel A merupakan membran yang direndam dalam larutan $\mathrm{HNO}_{3}$ dan $\mathrm{NaOH}$. Kandungan $\mathrm{NaOH}$ pada membran menambah sifat antibakteri. Penelitian mengenai perbandingan aktivitas antibakteri minyak kelapa virgin menunjukkan pemberian $25 \% \mathrm{NaOH}$ membentuk zona inhibit 9,20 mm, 50\% (9,03 mm) dan $75 \%(10 \mathrm{~mm})$ terhadap bakteri S. Aureus. ${ }^{13}$ Basis metal berupa alkalin seperti $\mathrm{NaOH}$ dan $\mathrm{KOH}$ memiliki kelarutan yang tinggi dan memiliki aktivitas

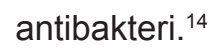

Penurunan koloni menjadi $\pm 52 \times 10^{6} \mathrm{CFU} /$ $\mathrm{ml}$ terjadi pada sampel $\mathrm{B}$ karena adanya apatit pada membran. Sampel B mengandung apatit $\left(\mathrm{Ca}^{2+}, \mathrm{PO}_{4}^{3-}\right.$, dan $\left.\mathrm{OH}^{-}\right)$dengan kadar $\mathrm{pH}$ 9-11 
yang menyebabkan terhambatnya pertumbuhan bakteri dan telah dipelajari dalam beberapa penemuan. Penelitian mengenai perbandingkan aktivitas antibakteri sejumlah larutan HA terhadap pertumbuhan Streptococcus mutans menunjukkan aktivitas antibakteri $200 \mathrm{mg}$ larutan HA menghambat pertumbuhan $S$. mutans pada media agar Brain Heart Infusion $(\mathrm{BHI}) .^{15}$

Seiring bertambahnya apatit yang terperangkap dalam pori-pori membran, aktivitas antibakteri semakin baik. Hal ini terlihat pada sampel $\mathrm{C}$ yang menunjukkan penurunan koloni dengan jumlah koloni $S$. aureus $\pm 34 \times 10^{5} \mathrm{CFU} / \mathrm{ml}$. Jumlah koloni semakin sedikit seiring lamanya perendaman scaffold dalam larutan SBF yaitu $\pm 18 \times 10^{5} \mathrm{CFU} / \mathrm{ml}$ pada sampel $\mathrm{D}$, dan $\pm 14 \times 10^{5} \mathrm{CFU} /$ $\mathrm{ml}$ pada sampel $\mathrm{E}$.

Kandungan hidroksiapatit yang semakin meningkat pada sampel $\mathrm{C}, \mathrm{D}$, dan $\mathrm{E}$ menaikkan $\mathrm{pH}$ membran. Sifat alkali memiliki efek menghancurkan membran sel dan struktur protein bakteri. ${ }^{16}$ Sifat alkali didapat dari tingginya konsentrasi ion hidroksil pada larutan karbonat apatit dan SBF. Ion $\mathrm{OH}^{-}$berperan aktif menghambat pertumbuhan bakteri. Ion hidroksil $\left(\mathrm{OH}^{-}\right)$yang mengandung oksidan merupakan radikal bebas yang reaktif dan bereaksi dengan beberapa biomolekul. ${ }^{7}$ Mekanisme yang mungkin terjadi yaitu induksi ion hidroksil bereaksi dengan membran sel, dan komponen seperti mitokondria yang menyebabkan perubahan ireversibel dalam struktur bakteri. Hal ini mengakibatkan hilangnya aktivitas biologis enzim dan gangguan metabolisme seluler. ${ }^{17}$

\section{KESIMPULAN}

Kesimpulan penelitian ini yaitu scaffold membran cangkang telur yang diaktivasi karbonat apatit mengandung bahan bioaktif, bersifat biodegradasi dan menunjukkan aktivitas antibakteri.

\section{DAFTAR PUSTAKA}

1. Steiner A, Yuan L, Dai S. Preparation of Well-Dispersed Superparamagnetic Iron Oxide Nanoparticles in Aqueous Solution with Biocompatible N-Succinyl-
O-carboxymethylchitosan. Journal Phisico Chemistry. 2008; 112: 5432-5438.

2. Gaetti-Jardim Jr. E, Fardin AC, Gaetti-Jardim EC, de Castro AL, Schweitzer CM, AvilaCampos MJ. Microbiota Associated with Chronic Osteomyelitis of The jaw.Journal of Microbiology. 2010; 41:1056-1064.

3. Indrani DJ. Preparasi Nanokristalin Hidroksiapatit untuk Scaffold Rekayasa Jaringan Tulang.Jurnal Sains Material Indonesia. 2012; 4: 36-39.

4. Lee Seung-Mo, Grass G, Kim Gyeong-Man, Dresbach C, Zhang L, Goseleand U, Knez M. Low-temperature $\mathrm{ZnO}$ Anatomic Layer Deposition on Biomembrane Supports: Flexible Photocatalytic $\mathrm{ZnO}$ Structures from Eggshell Membranes, Phys. Chem. Chem. Phys. 2009; 11: 3608-3614.

5. Ikaningsih MA. Sintesis Membran Hidroksiapatit Menggunakan Egg-Shell Membrane sebagai Membrane Support dengan Metode Self Assembly. Banudung: Institut Teknologi Bandung.Tesis. 2011.

6. Shepherd JH, Shepherd DV, Best SM. Substituted Hydroxyapatites for Bone Repair, Journal Material Science: Material Medical. 2012; 23(10): 2335-2347.

7. Aruoma OI, Cuppett SL. Antioxidant Methodology: In Vivo and in vitro Concepts. USA: AOCS Press. 2000

8. Ohtsuki C. How to Prepare The Simulated Body Fluid (SBF) and Its Related Solutions [internet]. 2012. http://mswebs.naist.jp/LABs/ tanihara/ohtsuki/SBF/index.html. Diakses pada tanggal 27 Juli 2014.

9. Rohaeti E. Pengaruh Variasi Berat Molekul Poli Etilen Glikol terhadap Sifat Mekanik Poliuretan. Jurnal Matematika dan Sains. 2009; 8: 2.

10. Tan $Q$, Fabrication of Pourous Scaffold with a Cintrollable Microstructure and Mechanical Propertiesby Porogen Fusion Technique. International Journal Science. 2011; 12: 890904 
11. Meyer U, Meyer T, Handschel J, Wiesmann HP. Fundamentals of Tissue Engineering and Regenerative Medicine. Berlin: SpringerVelag Berlin Heidelberg. 2009

12. Ardhananeswari D. Pengaruh Variasi Konsentrasi Kitosan terhadap Struktur Pori, Kekuatan Tekan dan Sifat Bioaktif pada Scaffold Hasil Sintesis. Purwokerto: Universitas Jenderal Soedirman. Skripsi. 2013.

13. Silalahi J, Yademetripermata, Putra EDL. Antibacterial Activity of Hydrolyzed Virgin Coconut Oil. Asian Journal Pharmacy Clinic Research. 2014; 7; 90-94.
14. Venigalla BS, Prasad KL, Singh VT, Jyotsna SV, Ghatole K. Comparison of Antibacterial Efficacy of Calsium Hydroxide with and without Addition of Herbal Medicament against Enterococcus Faecalis. 2014; 27: 38-41.

15. Tin-Oo MM, Gopalakrishnan V, Samsuddin AR, Al-Salihi KA, Shamsuria O. Antibacterial Property of Locally Produced Hydroxyapatite. Archives of Orofacial Sciences.2007; 2: 41-44.

16. Walton RE, Holton IF Jr., Michelich R. Calcium Hydroxide as an Intracanal Medication: Effect on Treatment Pain. Journal Endodontic. 2003; 29: 627-629.

17. Voet D, Voet JG.Biochemistry. 3 ed. New York: John Wiley \& Sons, Inc. 2004. 